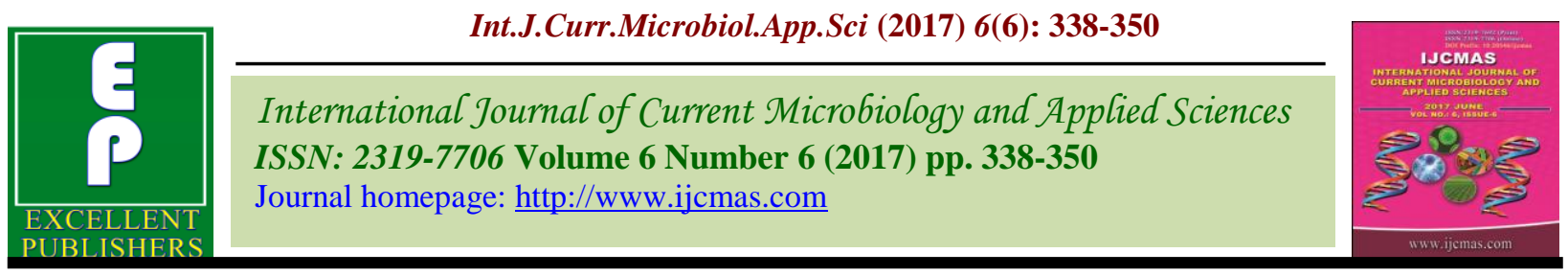

Original Research Article

https://doi.org/10.20546/ijcmas.2017.606.040

\title{
Rainfall Analysis for Suitability of Rainfed Rice Cultivation in Chhattisgarh State during Pre and Post Global Warming Period
}

\author{
Deepika Unjan*, A.S.R.A.S. Sastri, N. Manikandan, R. Singh and Uttam Diwan \\ Department of Agrometeorology, College of Agriculture, Indira Gandhi Krishi \\ Vishwavidhyalya, Raipur, Chhattisgarh 492012, India \\ *Corresponding author
}

\section{A B S T R A C T}

Present analysis was carried out for two different period's i.e., pre global warming period (1931-1970) and post global warming period (1971-2010) to find out the changes in seasonal and annual rainfall of 17 districts of Chhattisgarh. Results revealed that there are

Keywords

Rainfall,

Variability,

Land suitability,

Global warming,

Rainfed rice,

Chhattisgarh.

Article Info

\section{Accepted:}

04 May 2017

Available Online:

10 June 2017 changes in monthly and seasonal rainfall distribution in different districts between pre and post global warming period. When the per cent deviation was examined there was $35 \%$ decline in annual rainfall in Mahasamund followed by Raigarh (29\%) and least decrease was observed at Bastar (6\%) followed by Korba (7\%). Variability in annual rainfall during pre and post global warming periods indicated that the highest increase in CV was noticed in Raigarh district where the CV increased from 18 per cent to 30 per cent during post global warming period and in Rajanandgaon CV decreased from 29 to $22 \%$ during post global warming period. From the analysis of suitability of rice cultivation under rainfed condition based on the distribution of rainfall that during post global warming none of the districts was highly suitable for rainfed rice cultivation. The worst affected district is Mahasamund followed by Raigarh and Narayanpur. These districts came under category 1 (highly suitable for rainfed rice cultivation) during pre-global warming period and during post global warming period rainfed rice cultivation no longer suitable. Immediate crop diversification with other suitable crops (less water requirement and short duration) in lieu of rainfed rice and also popularizing water/soil conservation technology like On Farm Reservoir (OFR) and System of Rice Intensification (SRI) should be taken in order to avoid further degradation of ecosystem.

\section{Introduction}

In rainfed cultivation rainfall plays an important role. In India South west monsoon rainfall contributions is about $85 \%$ of the annual rainfall. However the rainfall situation varies from year to year and the rainfall deviations from normal values result in drought conditions. Kandiannan et al., (2008) carried of rainfall analysis of the high rainfall tract of agroclimatic zone of Kerala. Saha and Sibamoy De (2008) studied the rainfall pattern during kharif season. Deka et al., (2009) reported in Nadia district of West Bengal rainfall was always been affected by uneven distribution of south-west monsoon.

The Chhattisgarh state is known as 'rice bowl of the country' because paddy is the major crop covering around $70 \%$ of net sown area during kharif (June - October) season. It is well recognized that climate is changing in 
most parts of the world and Chhattisgarh state is no exception. There are many studies stating that there have been a lot of changes in precipitation amount and its pattern and rising of atmospheric temperature at national, state and district level and suggesting cropping pattern should be in accordance with climatic, edaphic and topographic factors of a particular region. Sastri et al., (1999) analyzed to find out suitable areas in Chhatisgarh state (Fig. 1) for rainfed rice cultivation based on annual rainfall amount and found that rainfed rice cultivation under transplanting condition is possible in areas receiving more than $1600 \mathrm{~mm}$ and crop diversification is needed in areas where annual rainfall less than $1200 \mathrm{~mm}$. In India, the productivity of rice increased because of augmentation of irrigation facility, development of high yielding varieties and improved management practices. However, in eastern part of India especially in Chhattisgarh this scenario is not realized due to diverse crop growing environments, land situations, physiographic and socio-economic conditions of the farmers. According to Planning Commission, Government of India (PC-GoI, 2011), rural areas of Chhattisgarh state are most vulnerable to impacts of disasters and climate change and they stated that with a significant population dependent on rain-fed agriculture, animal husbandry, fisheries, and forest-based livelihoods, any change in precipitation and temperature patterns could significantly impact lives of the vulnerable communities. Hence, there is a necessity to analyze the agroclimate conditions for rice cultivation in the back drop of climate change scenario. Keeping the above facts in view an effort has been made to find out changes in seasonal and annual rainfall at district level and also to analyze the suitability for rainfed rice cultivation during pre (1931-1970) and post (1971-2010) global warming periods in different districts of Chhattisgarh.
In Chhattisgarh rice is grown in around 3.6 lakh ha. Of which about $27 \%$ area is under irrigation and the rest of the area is under rainfed condition. The productivity of the rice in Chhattisgarh depends upon rainfall quantum and distribution during the study period. Sastri et al., (1999) studied the effective stable rainfall periods in different district of Chhattisgarh. The stable rainfall was defined as the amount where the weekly rainfall is more $50 \mathrm{~mm}$ and corresponding coefficient of variance $(\mathrm{CV})$ is less than $100 \%$. Also the crop varietal selection depends upon the length of growing period specially humid period and hence rainfall analysis in temporal and special trams is very important in determining the impact of rainfall distribution on the rice productivity.

In view of this an attempt is made to study the rainfall distribution in Chhattisgarh state in the back drop of changing climatic scenario.

\section{Materials and Methods}

\section{Study area}

Chhattisgarh state came in to existence on 1st November, 2000, as result of bifurcation of the state of Madhya Pradesh. Chhattisgarh state, situated in Eastern India, is located between $17^{\circ} 46^{\mathrm{ce}} \mathrm{N}$ and $24^{\circ} 5^{\mathrm{ec}} \mathrm{N}$ latitudes and $84^{\circ} 15^{\mathrm{ee}} \mathrm{E}$ and $84^{\circ} 24^{\mathrm{ee}} \mathrm{E}$ longitudes. It is surrounded in the west by Madhya Pradesh and Maharashtra, in the north by Madhya Pradesh, in the east by Orissa and Jharkhand (the new state separated from Bihar) and in the south by Andhra Pradesh.

The state has 27 districts viz. Raipur, Mahasamund, Rajnandgaon, Durg, Dhamtari, Kawardha, Bilaspur, Janjgir Champa, Korba, Jashpur, Raigarh, Surguja, Koria, Kanker,,Dantewada, Narayanpur, Bijapur Blrampur, Surajpur, Balodabajar, Bemetara, Balod, 
Gariyaband, Kondagaon, Sukhama, Mugeli,Bastar (Jagdalpur). Spreading over a geographical area of 137.90 lakh hectares.

\section{Rainfall analysis}

For the analysis of rainfall daily weather data was considered for all the district of Chhattisgarh state. The rainfall data was converted in monthly rainfall and standard deviation and its coefficient of variance were worked out of assessing the status of rainfall condition in each month base on mean month in rainfall different of categories for assessing the suitability of rainfed cultivation as given bellow (Table 1).

Based on the distribution of rainfall for the months of June, July, August and September using the above criteria the suitability of the rainfed rice cultivation each district is categorized as follows:

Using the criteria the suitability of rainfall during pre global warming period (19311970 ) and post global warming period (19712010) have been for examining the worked out and mapped change in the situations of rainfed rice cultivation in different districts.

\section{Stable rainfall period}

A stable rainfall period for rainfed rice crop is defined as the period when weekly rainfall is greater than $50 \mathrm{~mm}$ and corresponding coefficient of variation is less than 100 per cent". The $50 \mathrm{~mm} /$ week is considered due to the fact that the daily ET rate of rice crop is around $4 \mathrm{~mm}$ and percolation rate is $3 \mathrm{~mm}$. Thus the total water requirement per day is $7 \mathrm{~mm}$ or $50 \mathrm{~mm} /$ week.

Using the above criteria the stable rainfall periods for four districts of Chhattisgarh representing four division of Chhattisgarh through graphical interpolation.

\section{Water availability period}

The water availability periods are the periods where the rainfall is balanced against the evaporative demand of the atmosphere, which is called "potential evopotranspiration". The water availability periods as defined by Cockeme and Franqling are as follows.

Using this criteria Water availability period for the four represented stations have graphical interpolation and length of growing period, that is, the total of humid and moist period was worked out.

\section{Potential evopotranspiration}

The potential evopotranspiration required for the analysis of water availability period using Pann Man equation (1955) with the help of weather cock software developed by CRIDA Hyderabad.

\section{Results and Discussion}

\section{Changes in seasonal and annual rainfall between pre and post global warming period}

Comparative study of seasonal and annual rainfall statistics between pre and post global warming periods was carried out and the results are shown in table 3 . It is interesting to note from table that in all the district's annual rainfall decreased in post global warming period. When the per cent deviation between pre and post global warming period was examined, there was $35 \%$ decrease in annual rainfall in Mahasmund followed by 29\% decline in Raigarh district and 23\% in Dhamtari district. Sastri (2009) reported that annual rainfall of Mahasamund and Kanker districts had decreased drastically by the end of 20th century. The least decrease of annual rainfall was observed in Bastar with 6\% followed by Korba with 7\% decrease. In other 
districts rainfall decreased from 29 to $12 \%$. Murali and Afifi (2014) studies indicated that slight decrease in annual rainfall of Janjgir Champa district during the period $1981-2010$. Their Participatory Rural Appraisal interaction with 180 households in the four villages of Janjgir Champa district revealed that majority of the households $(58.3 \%)$ have not observed any floods over the past three decades (1981-2010). However, 34\% of the households sensed that the droughts and dry spells have increased. They also reported that number of rainy days has declined from 65 to 56 in the past decade in Janjgir Champa district.

Similar pattern of decreasing of rainfall was observed in southwest monsoon season which contributes up to 90 percent to annual rainfall. Highest decrease was seen in Mahasamund (35\%) followed by Raigarh (31\%) and Dhamtari $(21 \%)$. Slight negative deviation was noticed in Korba (4\%) and Bastar (7\%) districts between pre and post global warming period (Table 3). From this it can be inferred that if this trend continues there would be less water available during main crop growing season (June-September) and it leads to frequent crop failures under rainfed condition. Therefore farmers might go for bore wells to exploit the groundwater resources to save their crops. Swain et al., (2015) did trend analysis of monthly rainfall data for Raipur district, Chhattisgarh for the period of 102 years (1901 to 2002) and results revealed a significant decrease for the months of southwest monsoon. The studies of Chakraborty et al., (2013) indicated an overall downward trend in annual and seasonal rainfall during the study period (1960-2008) over Seonath River Basin of Chhattisgarh State. They also pointed out that the change has occurred in 1980.

In case of post monsoon season (Oct-Nov), in state as a whole, 12 percent decrease was noticed between pre and post global warming period with highest decrease (-39\%) in Mahasamund district (Table 3). The decrease in rainfall during this season especially in the month of October, would severely affect the paddy production in the state. The grain formation and development stage of paddy requires sufficient soil moisture in soil and soil moisture stress due to failure of rainfall in this month leads yield reduction. Sastri (2009) reported that as a consequence of decreasing rainfall trends, especially in the month of October, the long duration varieties started failing and farmers have more and more relied on short or medium duration rice varieties for the past 10 years. The results of Rathore et al., (2013) also agreed with present study that rainfall in October month showing decreasing tendency during their study period 19512010.

\section{Changes in seasonal and annual rainfall variability between pre and post global warming period}

When coefficient of variation (CV) of annual rainfall between pre and post global warming period are scrutinized it was found that in Rajanandgaon district CV decreased from 29 to $22 \%$ while in Bijapur the $\mathrm{CV}$ value decreased from $20 \%$ during pre-global warming period to $16 \%$ during post global warming period (Table 5). In Janjgir Champa and Korba districts slight decrease $(1 \%)$ is observed in annual CV. However, in other districts the $\mathrm{CV}$ values increased during post global warming period which indicates variability in inter annual rainfall is rising and dependability is reducing. The highest increase in annual CV was noticed in Raigarh district where the CV increased from 18 per cent during pre-global warming period to 30 per cent during post global warming period. This is followed by Surguja, Durg and Kanker districts where the CV values increased to 29, 29 and 27 per cent respectively during post global warming period. 
Changes in coefficient of variation for southwest monsoon rainfall indicate that in all districts rainfall variability has been increased except Bastar and Korba. Highest change is noticed in Mahasamund, Raigarh and Surguja districts where $\mathrm{CV}$ has leaped to 35, 30 and 30 percent in post global warming period, respectively (Table 5). This increase in inter annual and seasonal rainfall variability is a cause of concern especially under rainfed condition. The results of Murali and Afifi (2014) indicated that $34 \%$ of the households sensed that the droughts and dry spells have increased, $18 \%$ of which even believe that the droughts and dry spells are currently 'a lot more' than before in Janjgir Champa district of Chhattisgarh.

\section{Suitability of rainfed rice cultivation during pre and post global warming period}

The suitability of rice crop under rainfed conditions during pre and post global warming periods was assessed as explained in methodology section and results are shown in figure 2 .

It can be seen from the figure that Mahasamund, Narayanpur and Raigarh districts come under highly suitable category during pre-global warming period. In these districts even transplanting could be done under rainfed condition. Rainfed rice cultivation could be done under traditional biasi system with the improved technology in Bastar, Kanker, Rajnandgaon and Raipur districts as these districts falling under category 2. Other districts except Bilaspur and Kabirdham falls under category 3, where rainfed rice cultivation is normally possible with good management and improved technique. The analysis also indicated that during pre-global warming period, rainfed rice cultivation is not economically suitable and crop diversification is necessary in near future in Bilaspur district and immediate crop diversification needed in Kabirdham district (Table 2).

Table.1 Monthly rainfall amount and category for suitability of rainfed rice cultivation

\begin{tabular}{|l|l|}
\hline Category & Monthly rainfall (mm) \\
\hline A + & Greater than 400 \\
\hline A & $300-400$ \\
\hline B & $200-300$ \\
\hline C & $100-200$ \\
\hline D & $50-100$ \\
\hline E & Less than 50 \\
\hline
\end{tabular}

Table.2 Category and description for assessing suitability of rainfed rice cultivation

\begin{tabular}{|l|l|l|}
\hline S. No & Category & Description \\
\hline 1 & $\mathrm{~A}+{ }_{2} \mathrm{~B}_{2}$ & Highly suitable for rainfed rice cultivation even under transplanting condition. \\
\hline 2 & $\mathrm{~A}+{ }_{2} \mathrm{~B}_{2} / \mathrm{A}+{ }_{1} \mathrm{~A}_{1} \mathrm{~B}_{2}$ & $\begin{array}{l}\text { Highly suitable for rainfed cultivation of rice under traditional biasi system with } \\
\text { improved techniques available. }\end{array}$ \\
\hline 3 & $\begin{array}{l}\mathrm{A}_{2} \mathrm{~B}_{1} \mathrm{C}_{1} / \mathrm{A}+{ }_{1} \mathrm{~A}_{1} \mathrm{~B}_{1} \\
\mathrm{C}_{1}\end{array}$ & $\begin{array}{l}\text { Normally suitable for rainfed rice cultivation with good management and } \\
\text { improved techniques. }\end{array}$ \\
\hline 4 & $\mathrm{~A} 2 \mathrm{C} 2 / \mathrm{A} 1 \mathrm{~B} 1 \mathrm{C} 2$ & $\begin{array}{l}\text { Not economically suitable for rainfed rice cultivation. Crop diversification is } \\
\text { necessary in near future. }\end{array}$ \\
\hline 5 & Other combination & $\begin{array}{l}\text { Not economically suitable for rainfed rice cultivation. Immediate diversification } \\
\text { is necessary. }\end{array}$ \\
\hline
\end{tabular}


Table.3 District-wise seasonal and annual rainfall $(\mathrm{mm})$ in Chhattisgarh state during Pre and post global warming period

\begin{tabular}{|l|l|l|l|l|l|l|l|l|l|l|l|}
\hline \multirow{2}{*}{ District } & \multicolumn{3}{|l}{ Pre global warming period (1931-1970) } & \multicolumn{3}{l|}{ Post global warming period (1971-2010) } \\
\cline { 2 - 12 } & Winter & Summer & SWM & PM & Annual & Winter & Summer & SWM & PM & Annual \\
\hline Bastar & 28.5 & 137.0 & 1218.4 & 131.1 & 1514.9 & 35.0 & 138.0 & 1130.4 & 119.1 & 1422.5 \\
\hline Bijapur & 16.7 & 80.2 & 1450.9 & 105.4 & 1653.2 & 4.1 & 44.2 & 1294.6 & 103.3 & 1446.2 \\
\hline Bilaspur & 49.2 & 53.8 & 1200.6 & 55.3 & 1358.8 & 37.3 & 45.8 & 1032.8 & 73.2 & 1189.1 \\
\hline Dantewada & 14.7 & 90.1 & 1301.8 & 114.5 & 1521.1 & 4.9 & 4.9 & 1103.0 & 102.5 & 1215.3 \\
\hline Dhamtari & 27.7 & 60.2 & 1191.8 & 75.5 & 1355.3 & 17.9 & 28.4 & 936.7 & 59.9 & 1043.0 \\
\hline Durg & 35.7 & 57.2 & 1117.6 & 72.6 & 1283.1 & 12.0 & 31.8 & 931.6 & 64.7 & 1040.1 \\
\hline Janjgir & 43.1 & 42.5 & 1231.0 & 46.5 & 1363.1 & 32.6 & 16.4 & 1133.7 & 45.2 & 1227.9 \\
\hline Kanker & 27.3 & 81.4 & 1152.3 & 99.1 & 1360.1 & 24.1 & 32.1 & 975.8 & 70.9 & 1095.2 \\
\hline Kabirdham & 42.0 & 44.8 & 976.7 & 76.0 & 1139.6 & 28.4 & 34.4 & 785.2 & 58.1 & 906.1 \\
\hline Korba & 39.2 & 34.6 & 1236.2 & 59.1 & 1369.0 & 23.6 & 23.4 & 1183.6 & 44.6 & 1275.2 \\
\hline Koriya & 56.5 & 46.4 & 1201.4 & 53.8 & 1358.1 & 26.7 & 14.4 & 1066.6 & 48.3 & 1155.9 \\
\hline Mahasamund & 29.2 & 94.4 & 1316.4 & 70.5 & 1464.5 & 13.6 & 39.2 & 851.5 & 43.2 & 947.4 \\
\hline Narayanpur & 27.1 & 103.8 & 1284.2 & 94.9 & 1509.9 & 10.6 & 21.8 & 1187.1 & 86.9 & 1306.5 \\
\hline Raigarh & 45.6 & 54.6 & 1518.8 & 62.0 & 1681.0 & 29.1 & 60.2 & 1053.9 & 44.0 & 1187.2 \\
\hline Rajnandgaon & 34.6 & 49.1 & 1278.1 & 83.3 & 1487.7 & 33.9 & 30.3 & 1026.0 & 68.8 & 1159.1 \\
\hline Surguja & 52.4 & 48.4 & 1320.6 & 63.8 & 1485.3 & 48.0 & 45.6 & 1150.4 & 58.1 & 1302.2 \\
\hline Raipur & 32.9 & 57.8 & 1211.4 & 60.9 & 1362.9 & 33.0 & 57.6 & 1034.5 & 69.8 & 1194.9 \\
\hline
\end{tabular}

Table.4 Stable rainfall periods in Ambikapur, Bilaspur, Jagdalpur and Raipur stations of Chhattisgarh

\begin{tabular}{|c|c|c|c|}
\hline S.No & Stations & Stable Rainfall Period & Totle days \\
\hline 1. & Ambikapur & 21June -22 September & 95 days \\
\hline 2. & Bilaspur & 20June - 14 September & 87 days \\
\hline 3. & Jagdalpur & 16 June - 21September & 98 days \\
\hline 4. & Raipur & 03 July - 22 September & 80 days \\
\hline
\end{tabular}


Table.5 District-wise seasonal and annual co-efficient of variation for rainfall (\%) in Chhattisgarh state during pre and post global warming period

\begin{tabular}{|l|l|l|l|l|l|l|l|l|l|l|}
\hline \multirow{2}{*}{ District } & \multicolumn{3}{|l|}{ Pre global warming period (1931-1970) } & \multicolumn{3}{|l|}{ Post global warming period (1971-2010) } \\
\cline { 2 - 11 } & Winter & Summer & SWM & PM & Annual & Winter & Summer & SWM & PM & Annual \\
\hline Bastar & 126 & 37 & 19 & 64 & 15 & 179 & 57 & 19 & 73 & 19 \\
\hline Bijapur & 147 & 73 & 22 & 67 & 20 & 272 & 172 & 23 & 91 & 16 \\
\hline Bilaspur & 73 & 83 & 21 & 104 & 20 & 113 & 119 & 23 & 102 & 22 \\
\hline Dantewada & 141 & 61 & 22 & 66 & 19 & 358 & 250 & 24 & 103 & 23 \\
\hline Dhamtari & 107 & 103 & 22 & 86 & 22 & 150 & 151 & 25 & 123 & 24 \\
\hline Durg & 100 & 73 & 23 & 98 & 22 & 170 & 164 & 28 & 106 & 29 \\
\hline Janjgir & 75 & 97 & 20 & 94 & 20 & 140 & 167 & 21 & 100 & 19 \\
\hline Kanker & 97 & 77 & 23 & 73 & 21 & 146 & 127 & 28 & 99 & 27 \\
\hline Kabirdham & 108 & 100 & 20 & 86 & 20 & 164 & 107 & 23 & 92 & 22 \\
\hline Korba & 120 & 114 & 26 & 105 & 26 & 149 & 157 & 26 & 181 & 25 \\
\hline Koriya & 50 & 112 & 22 & 119 & 22 & 132 & 153 & 27 & 122 & 24 \\
\hline Mahasamund & 111 & 313 & 24 & 93 & 32 & 159 & 363 & 35 & 142 & 37 \\
\hline Narayanpur & 105 & 71 & 17 & 75 & 18 & 230 & 169 & 18 & 89 & 19 \\
\hline Raigarh & 89 & 84 & 19 & 87 & 18 & 102 & 154 & 30 & 78 & 30 \\
\hline Rajnandgaon & 123 & 105 & 29 & 102 & 29 & 93 & 105 & 25 & 91 & 22 \\
\hline Surguja & 86 & 83 & 20 & 90 & 21 & 83 & 100 & 30 & 75 & 29 \\
\hline Raipur & 94 & 83 & 26 & 106 & 25 & 126 & 134 & 27 & 109 & 28 \\
\hline
\end{tabular}

Table.6 Water availability period under different rainfall station at Raipur, Bilaspur, Jagdalpur and Raipur stations of Chhattisgarh

\begin{tabular}{|c|c|c|c|c|c|}
\hline Station & Year & Moist $1^{\text {st }}$ & Humid period & Moist $2^{\text {nd }}$ & $\begin{array}{l}\text { Total } \\
\text { Period }\end{array}$ \\
\hline Ambikapur & $1991-2012$ & $\begin{array}{l}27 \text { May - } 9 \text { Jun. } \\
\text { (13 days) }\end{array}$ & $\begin{array}{l}\text { 10 Jun -7 Oct. } \\
\text { (119 days) }\end{array}$ & $\begin{array}{l}8 \text { Oct }-17 \text { Oct. } \\
(10 \text { days })\end{array}$ & 141 Days \\
\hline Bilaspur & $1983-2012$ & $\begin{array}{l}26 \text { May - } 9 \text { Jun. } \\
\text { (14 days) }\end{array}$ & $\begin{array}{l}\text { 10 Jun -1 Oct. } \\
\text { (113 days) }\end{array}$ & $\begin{array}{l}2 \text { Oct }-13 \text { Oct. } \\
(12 \text { days })\end{array}$ & 139 Days \\
\hline Jagdalpur & $1980-2012$ & $\begin{array}{l}\text { 16 May -28 May } \\
\text { (13 day) }\end{array}$ & $\begin{array}{l}29 \text { May }-10 \text { Oct. } \\
\text { (135 days) }\end{array}$ & $\begin{array}{l}11 \text { Oct - } 4 \text { Nov. } \\
(25 \text { days })\end{array}$ & 173 Days \\
\hline Raipur & $1971-2012$ & $\begin{array}{l}27 \text { June - } 16 \text { June } \\
\text { (14 days) }\end{array}$ & $\begin{array}{l}\text { 17Jun -31 Sep. } \\
\text { (105 days) }\end{array}$ & $\begin{array}{l}1 \text { Oct }-11 \text { Oct. } \\
\text { (11 days) }\end{array}$ & 130 Days \\
\hline
\end{tabular}


Fig.1 Three agro-climatic zones in Chhattisgarh

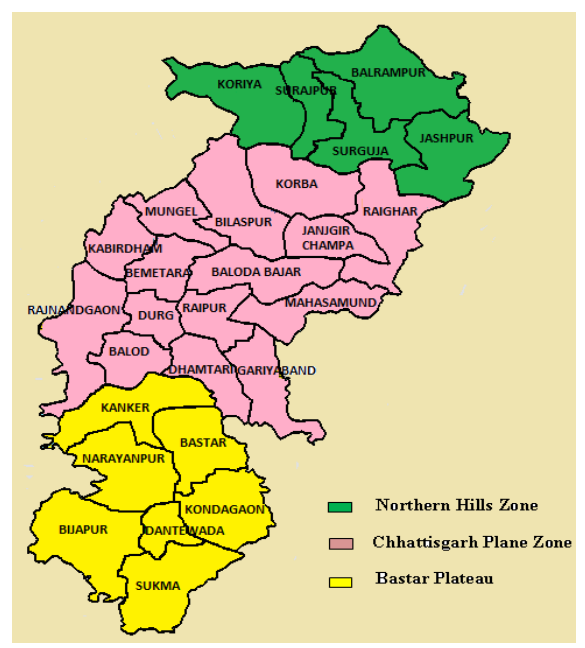

Fig.2 Changes in suitability condition for rainfed rice cultivation during pre and post global warming period in different districts of Chhattisgarh state

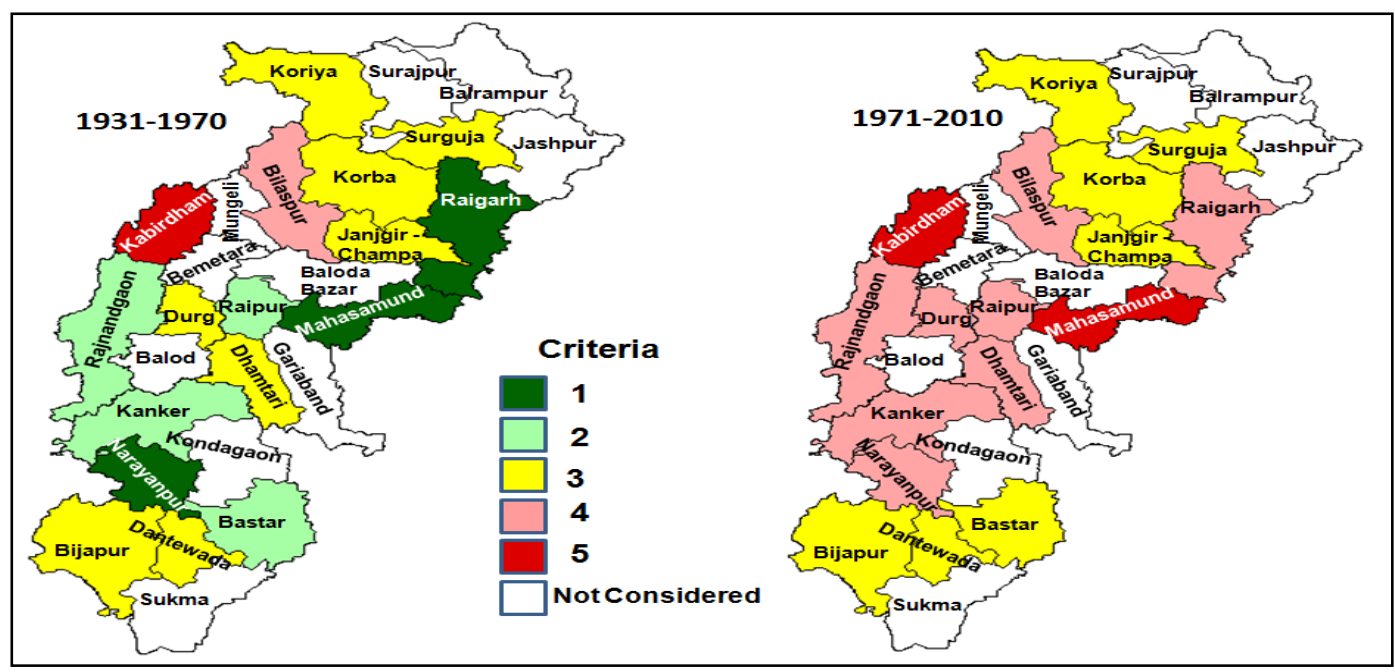

\begin{tabular}{|l|l|l|}
\hline S. No & Color & Description \\
\hline 1 & $\square$ & $\begin{array}{l}\text { Highly suitable for rainfed rice cultivation even under transplanting } \\
\text { condition. }\end{array}$ \\
\hline 2 & $\square$ & $\begin{array}{l}\text { Highly suitable for rainfed cultivation of rice under traditional biasi } \\
\text { system with improved techniques available. }\end{array}$ \\
\hline 3 & $\square$ & $\begin{array}{l}\text { Normally suitable for rainfed rice cultivation with good management and } \\
\text { improved techniques. }\end{array}$ \\
\hline 4 & $\square$ & $\begin{array}{l}\text { Not economically suitable for rainfed rice cultivation. Crop diversification } \\
\text { is necessary in near future. }\end{array}$ \\
\hline 5 & $\square$ & $\begin{array}{l}\text { Not economically suitable for rainfed rice cultivation. Immediate } \\
\text { diversification is necessary. }\end{array}$ \\
\hline 6 & $\square$ & Not considered \\
\hline
\end{tabular}


Fig.3 Stable rainfall periods in different districts of Chhattisgarh
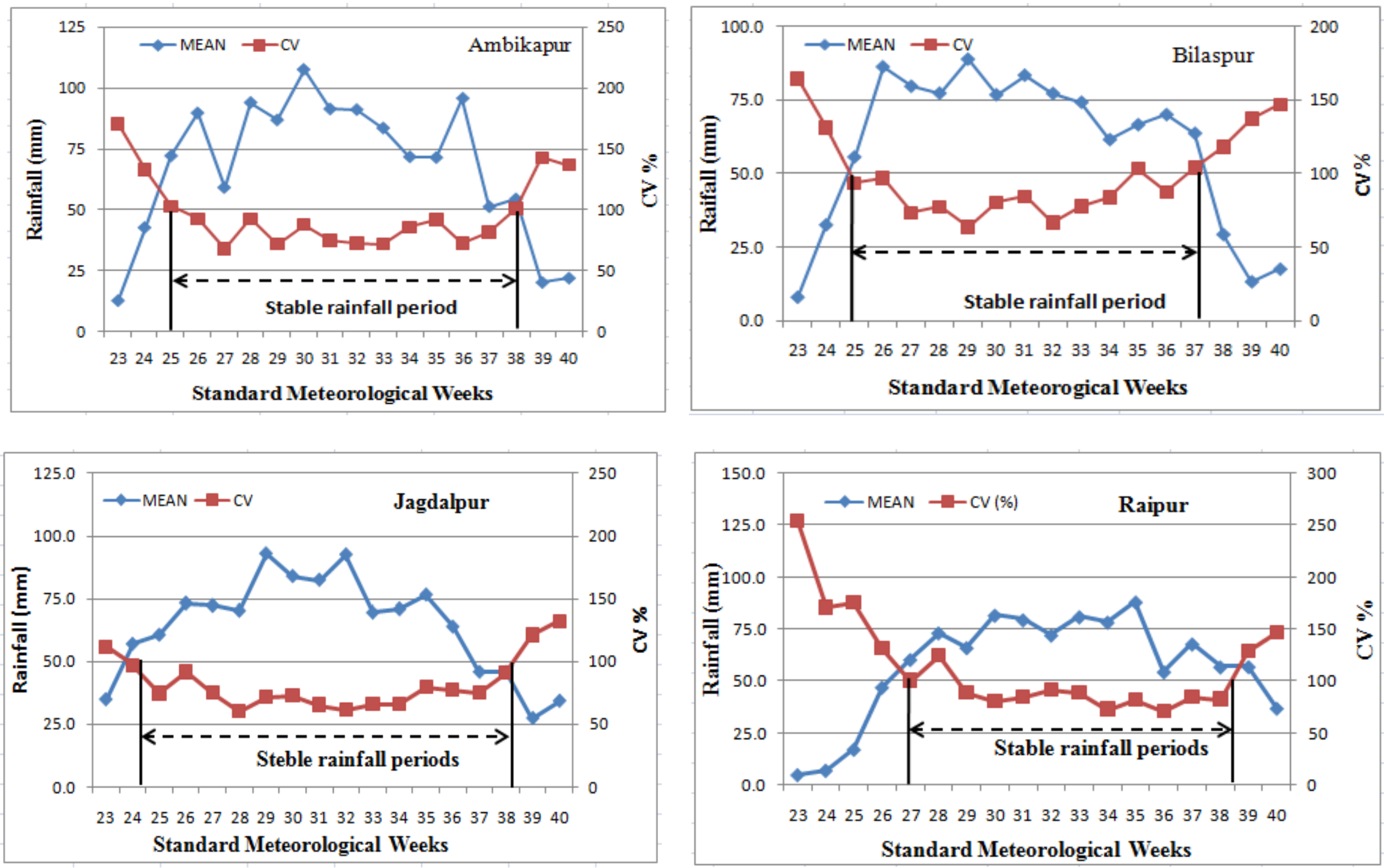


\section{Int.J.Curr.Microbiol.App.Sci (2017) 6(6): 338-350}

Fig.4 Water availability periods in different districts of Chhattisgarh
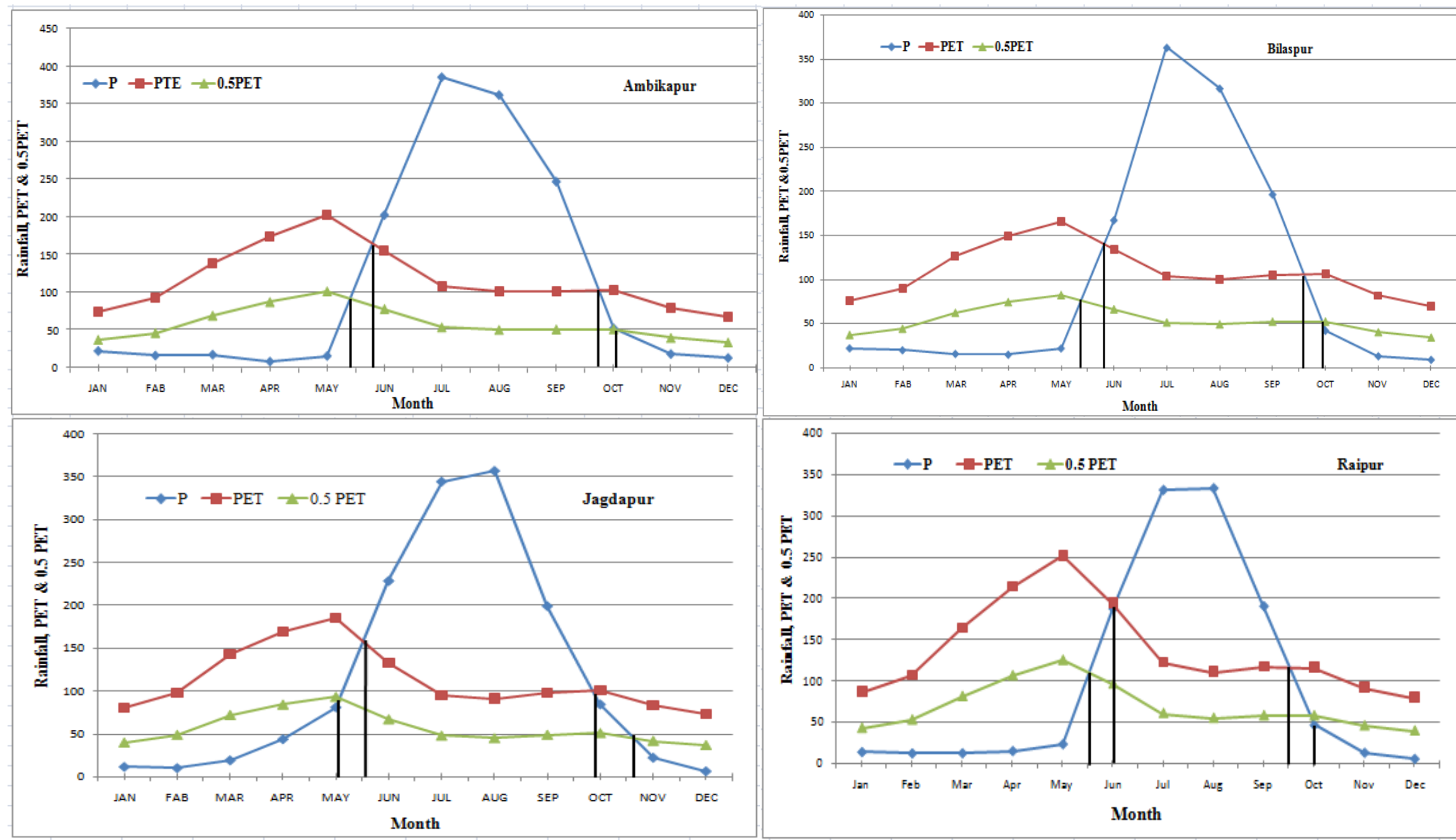
None of the districts was highly suitable for rainfed rice cultivation under transplanting condition or traditional biasi system during post global warming period (Fig. 2). The districts like Surguja, Bijapur, Dantewada, Bastar, Janjgir Champa, Korba, Koriya are coming under category 3 i.e., normally suitable for rainfed rice cultivation with good management and improved techniques. Other districts are not economically suitable for rainfed rice cultivation except Kabirdham and Mahasamund. In Kabirdham and Mahasamund districts rainfed rice cultivation is not only economically on suitable but also immediate crop diversification is needed. Samanta et al., (2011) through multi-criteria decision approach analysis found that only 25 per cent of land falls under high / medium high category for rice cultivation in Morobe province of Papua New Guinea and 75 per cent of land are comes under medium / medium low / low category.

It can be inferred from the results of the present study that among all districts, the worst affected district is Mahasamund followed by Raigarh and Narayanpur. These districts came under category 1 (highly suitable for rainfed rice cultivation) during pre-global warming period and during post global warming period rainfed cultivations no longer economically suitable in these districts and immediate crop diversification is required. According to Sastri et al., (1999), in Chhattisagrh productivity of rice under rainfed ecosystem depends mainly on the vagaries of monsoon; under late onset of monsoon condition, less quantum of rainfall received during the season and rice yield also reduced by 27 per cent when compared to normal onset condition.

Paddy cultivation under rainfed ecosystem is going to be challenging task in many parts of India as well in Chhattisgarh in the ensuing years due to climate change / variability. On the other hand area, in Mahasamund district significant increase in rice area is noticed (from 233263 ha in 2000 to 266270 ha in 2011) whereas in Raigarh district such trend is not observed (www.dacnet.nic.in). It indicates that the farmers should adopt crop diversification from rainfed rice to other suitable crops (less water requirement and short duration) and also popularizing water / soil conservation technologies and system of Rice Intensification (SRI) is imperative.

\section{Stable rainfall period}

For assessing the suitability of rainfed rice cultivation, the analysis of determining the stable rainfall periods is helpful. The stable rainfall period can be worked out by graphical interpolation. The geographical the interpolation for the four stations is shown in figure 3. Here the mean of rainfall and corresponding $\mathrm{CV}$ values from 23 standard meteorological weeks to 40 standard meteorological weeks are considered. The results are shown table 4 . It can be seen from the table the stable rainfall period for Ambikapur station start from 21st June and ends by 22nd September. For Bilaspur stable rainfall period starts from 20th June and ends 14th September. At Jagdalpur stable rainfall period starts earlier 16th June and ends by on 21st September. At Raipur stable rainfall period starts from 03rd July and ends by 22nd September. At Raipur rainfall is unstable till 2nd July. This is a good concept for accessing the period of stable rice crop growth at different stations.

\section{Water availability period}

Unlike stable rainfall period, the water availability period indicates the field preparation stage of moist I and maturity stage as moist II. Periods in between moist I and moist II periods is suitable for vegetative and reproductive stages of rice crop. 
The graphical interpolations of water availability periods for different stations are shown in figure 4 . The results are shown in table 6. It can be seen from the table moist I period start form 27th May to 9th June at Ambikapur. This is period is suitable for field preparation of rice crop. The humid period at Ambikapur is from 10th June to 7th October which is 119 days. The moist II period at Ambikapur is from 8th October to 17th October which is suitable for maturity and harvest of crop. At Bilaspur 26th May to 9th June is moist I period which is suitable for field preparation of rice crop. The humid period of Bilaspur is from 10th June to October which is 139 days. The moist II period at Bilaspur is from 2nd October to 13th October which is suitable for maturity and harvest of rice crop.

At Jagdalpur, water availability period is 173 days which is higher as compared to all the other three stations. At Jagdalpur, the moist I period starts from 16th May to 28th May which is 13 days and humid period at 29th May to10 October which is 135 days. The humid period is suitable for vegetative growth. At Jagdalpur 11th October to 4th November is 25 days moist II period which is suitable for maturity. At Raipur station 27th June 16th June which is 14 days is moist I period. This period is suitable for field preparation of rice crop and the moist II period is from suitable for maturity and harvesting of rice. The humid period is from 17th June to 31st September which is 105 days. This indicates that under Raipur condition rice cultivation under rainfed condition is and only early or medium duration of rice varieties should be recommended.

In conclusion, the present study carried out to analyze rainfall statistics between pre (19311970) and post (1971-2010) global warming periods was at district level in Chhattisgarh state and also to find suitability for rainfed rice cultivation in the state based rainfall distribution. The results revealed that there are changes in monthly and seasonal rainfall distribution in different districts between pre and post global warming period. When the per cent deviation was examined there was $35 \%$ decrease of rainfall in Mahasmund followed by Raigarh $29 \%$ and least decrease in annual rainfall was observed at Bastar with $6 \%$ decrease followed by Korba with $7 \%$ decrease. While annual rainfall variability $(\mathrm{CV})$ indicates that, highest increase is noticed in Raigarh district where the $\mathrm{CV}$ increased from 18 per cent during pre-global warming period to 30 per cent during post global warming period. It is inferred from the analysis of suitability of rice cultivation under rainfed condition based on the distribution of rainfall that during post global warming that none of the districts are highly suitable / not economically suitable for rainfed rice cultivation. Immediate crop diversification with other suitable crops (less water requirement and short duration) in lieu of rainfed rice and also popularizing water / soil conservation technology like On Farm Reservoir (OFR) and System of Rice Intensification (SRI) should be taken in order to avoid further degradation of ecosystem. Further it is proposed to carry out land suitability analysis for rainfed rice cultivation in Chhattisgarh state based on climatic, edaphic, topographic and socio-economic factors along with remote sensing and GIS techniques to get more insight for effective utilization of land / natural resources for specific purpose and also to curtail the problem in rainfed rice cultivation as well as livelihood of rice farmers in Chhattisgarh state.

\section{References}

Addeo, G., Guastadisegni, G. and Pisante, M. 2001. Land and water quality for sustainable and precision farming. I World Congress on Conservation Agriculture, Madrid

Chakraborty, S., Pandey, R.P., Chaube, U.C. and Mishra, S.K. 2013. Trend and variability analysis of rainfall series at Seonath River Basin, Chhattisgarh (India). Int. Journal of Applied Sciences and Engineering Research. 2 (4): 425 434 
De La Rosa, D. 2000. Micro LEIS Conceptual Framework: Agro-ecological Land Evaluation. Instituto de Recursos Naturales y Agrobiologia, CSIC, Sevilla, Spain, 31p.

Deka, N., Lepcha, L., Nanda, M. K., Saha, G. and Sunil K.M. 2009. Winter rice production under changing rainfall pattern in Nadia district of West Bengal. Journal of Agrometeorology, 11(special issue): pp 61-63

FAO 1976. A framework for land evaluation: soils bulletin 32. Food and Agriculture Organization of the United Nations, Rome, Italy

Kandiannan, K., Thankamani, C. K. and Mathew, P. A. 2008. Analysis of rainfall of the high rainfall tract of northern agroclimatic zone of Kerala. Journal of Spices and Aromatic Crops E8.17 (1): pp 16-20.

Murali, J. and Afifi, T. 2014. Rainfall variability, food security and human mobility in the Janjgir-Champa district of Chhattisgarh state, India. Climate and Development. 6(1): 28-37

NCA. 1976. Climate and agriculture. Part IV. Report of National Commission on Agriculture.

PC-GoI. 2011. Faster, sustainable and more inclusive growth, an approach to the twelfth five year plan (2012-17), Planning Commission, Government of India, New Delhi.

Rathore, A.L., Pal, A.R., Sahu, R.K. and Chaudhary, J.L. 1996. On-farm rainwater and crop management for improving productivity of rainfed areas. Agricultural Water Management 31: 253-267.

Rathore, L.S., Attri, S.D. and Jaswal, A.K. 2013. State level climate change trends in India. Meteorological Monograph No. ESSO/IMD/EMRC/02/2013, India Meteorological Department, New Delhi, $147 \mathrm{p}$.

Samanta, S., Pal, B. and Pal, D. K. 2011. Land Suitability Analysis for Rice Cultivation Based on Multi-Criteria Decision Approach through GIS. Int. J Sci. Emerging Tech., 2 (1): 12-20

Sastri, A.S.R.A.S. 2009. Long range regional climate fluctuations/changes and their impacts on agriculture: A case study for Chhattisgarh State in Central India. Proceedings of workshop on Impact of climate change on agriculture (Eds: Sushma Panigrahy, Shibendu Shankar Ray, and Jai Singh Parihar). ISPRS Archives XXXVIII-8/W, Ahmedabad, pp. 156-160

Sastri, A.S.R.A.S., Rai, S.K., Naidu, D. and Srivastava, A.K. 1999. Influence of climate parameters on productivity of rainfed rice: A case study of Chattisgarh. In: Rice - in a variable climate (Eds. Abrol, Y. P. and Gadgil, S.) APC Publications Pvt. Ltd, Dew Delhi, pp. 5162

Swain, S., Verma, M. and Verma, M.K. 2015. Statistical trend analysis of monthly rainfall for Raipur district, Chhattisgarh. Int. J. Adv. Engg. Res. and Studies. 4: 87 $-89$.

www.imd.gov.in

\section{How to cite this article:}

Deepika Unjan, A.S.R.A.S. Sastri, N. Manikandan, R. Singh and Uttam Diwan. 2017. Rainfall Analysis for Suitability of Rainfed Rice Cultivation in Chhattisgarh State during Pre and Post Global Warming Period. Int.J.Curr.Microbiol.App.Sci. 6(6): 338-350. doi: https://doi.org/10.20546/ijcmas.2017.606.040 